\title{
Nilai, Size, Profitabilitas Perusahaan dan Praktik Perataan Laba
}

\author{
I Ketut Winanda ${ }^{1}$ \\ Fakultas Ekonomi dan Bisnis \\ Universitas Udayana, Indonesia
}

\author{
Ida Bagus Putra Astika ${ }^{2}$ \\ Fakultas Ekonomi dan Bisnis \\ Universitas Udayana, Indonesia
}

\begin{abstract}
Surel : ketutwinanda01@gmail.com
\section{ABSTRAK}

Pasar modal di Indonesia saat ini semakin berkembang, sehingga membuat persaingan antar perusahaan semakin meningkat. Perusahaan akan berusaha untuk meningkatkan nilai perusahaannya agar menarik minat investor untuk berinvestasi di perusahaan tersebut. Manajemen menyadari bahwa perhatian investor cenderung hanya terpusat pada laba, sehingga manajer terdorong untuk melakukan praktik perataan laba. Penelitian ini bertujuan untuk memperoleh bukti empiris pengaruh nilai perusahaan, ukuran perusahaan dan profitabilitas pada praktik perataan laba pada perusahaan perbankan yang terdaftar di Bursa Efek Indonesia periode 2016-2018. Jumlah sampel yang terpilih pada perusahaan perbankan adalah 31 perusahaan, dengan menggunakan metode purposive sampling. Teknik analisis data yang digunakan adalah analisis regresi logistik dan hasil penelitian menunjukkan bahwa nilai perusahaan dan ukuran perusahaan berpengaruh positif pada praktik perataan laba, sedangkan profitabilitas tidak berpengaruh pada praktik perataan laba.
\end{abstract}

Kata Kunci: Praktik Perataan Laba; Nilai Perusahaan; Ukuran Perusahaan; Profitabilitas.

\section{Value, Size, Company Profitability and Income Smoothing Practices}

\section{ABSTRACT}

The capital market in Indonesia is currently growing, so that competition between companies is increasing. The company will try to increase the value of the company in order to attract investors to invest in the company. Management realizes that attention investors tend to only focus on profit, so managers are encouraged to practice income smoothing. This study aims to obtain empirical evidence of the influence of firm value, firm size and profitability on income smoothing practices in banking companies listed on the Indonesia Stock Exchange for the 2016-2018 periode. The number of samples selected in banking companies is as many as 31 companies, using the purposive sampling method. The data analysis technique used is a logistic regression analysis and the results showed that the firm value and firm size had a positive effect on income smoothing practices, while the profitability did not effect the income smoothing practice.

Keywords: Income Smoothing; Firm Value; Firm Size; Profitability.

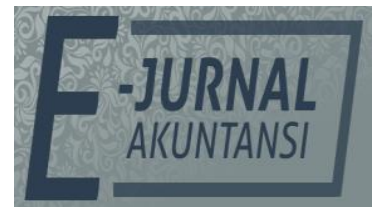

e-ISSN 2302-8556

Vol. 31 No. 3

Denpasar, Maret 2021

Hal. 562-576

DOI:

10.24843/EJA.2021.v31.i03.p04

PENGUTIPAN:

Winanda, I K., \& Astika,

I.B.P. (2021). Nilai, Size,

Profitabilitas Perusahaan dan Praktik Perataan Laba.

E-Jurnal Akuntansi, 31(3),

562-576

RIWAYAT ARTIKEL:

Artikel Masuk:

29 Mei 2020

Artikel Diterima:

21 Juli 2020

Artikel dapat diakses : https://ojs.unud.ac.id/index.php/Akuntansi/index 


\section{PENDAHULUAN}

Informasi mengenai laba dalam laporan keuangan merupakan informasi yang penting. Sesuai dengan Statement of Financial Concepts (SFAC) No.8 menyatakan bahwa selain untuk menilai kinerja manajemen, laporan keuangan juga membantu manajemen dalam mengestimasi kemampuan laba yang representatif dalam jangka panjang serta menaksir risiko dalam investasi atau kredit. Investor cenderung hanya terpaku pada laba yang tersaji dalam laporan keuangan tanpa memperhatikan prosedur yang digunakan oleh manajemen dalam menghasilkan laba tersebut (Beattie 1994). Begitu pentingnya informasi laba ini menyebabkan manajer melakukan tindakan yang membuat laba akan terlihat lebih stabil. Hal tersebut disebabkan laba yang stabil menunjukkan keberhasilan kinerja manajemen di mata investor. Salah satu cara yang sering digunakan oleh manajer adalah manajemen laba.

Manajemen laba terjadi ketika para manajer mengatur pelaporan keuangan dengan mengelola transaksi sehingga mengubah laporan keuangan (Fischer \& Rosenzweig, 1995). Menurut Gantino (2015) salah satu pola dari manajemen laba adalah perataan laba (income smoothing). Tudor (2002) menjelaskan bahwa perataan laba adalah suatu tindakan manajemen perusahaan untuk meredam fluktuasi laba yang dilaporkan dari waktu ke waktu, serta bertujuan untuk memaksimalkan kekayaan perusahaan, mengurangi risiko perusahaan, meningkatkan nilai perusahaan, memenuhi perjanjian utang, mengurangi pajak dan biaya politik. Manajemen ingin mendapatkan penilaian yang baik dari investor dan menarik investor untuk berinvestasi.

Wang \& Williams (2011) menjelaskan bahwa investor akan lebih tertarik membeli saham perusahaan dengan laba yang stabil dibandingkan perusahaan dengan fluktuasi laba yang tinggi. Praktik perataan laba dapat dilakukan dengan dua cara, yaitu naturally smooth dan intentionally being smoothed by management (Musthaq et al., 2016). Naturally smooth (perataan secara alami) merupakan perataan laba dalam proses perolehan laba manajemen memilih menggunakan metode akuntansi yang lebih representatif atas keadaan perusahaan sebenarnya dengan asumsi bahwa metode sebelumnya sudah tidak relevan lagi untuk digunakan (sesuai batas-batas Standar Akuntansi Keuangan), sedangkan intentionally being smoothed by management (perataan yang disengaja) merupakan perataan laba yang terjadi ketika pihak manajemen memanipulasi waktu pencatatan akuntansi seperti memindahkan beban atau pendapatan dari suatu periode ke periode lainnya. Menurut Obaidat (2017) menyatakan bahwa perataan laba yang baik terjadi ketika manajemen mampu menciptakan kinerja keuangan yang stabil dengan keputusan bisnis yang dapat diterima, sedangkan perataan laba yang buruk apabila manajemen mengakui penjualan fiktif sehingga dapat mempengaruhi laba.

Manajer melakukan perataan laba karena ada motivasi yang mendasarinya. Hejazi et al. (2011) mengemukakan beberapa alasan manajemen perusahaan melakukan praktik perataan laba, yaitu mengurangi jumlah pajak yang terutang yaitu dengan menurunkan jumlah laba dan menaikkan biaya yang dikeluarkan perusahaan pada periode berjalan, meningkatkan kepercayaan investor dan kreditur, sebab laba yang relatif stabil cenderung memiliki risiko yang lebih rendah dibandingkan dengan laba yang berfluktuasi, menjaga 
hubungan baik antara manajemen dengan kreditur, investor, dan karyawan, serta dapat memperbaiki citra perusahaan yaitu dengan menunjukkan bahwa risiko dari investasi pada perusahaan tersebut rendah. Ini dapat tercapai dengan asumsi bahwa indikator utama dalam menilai risiko suatu perusahaan adalah variabilitas laba.

Fenomena adanya praktik perataan laba ini telah memunculkan kasus dalam pelaporan akuntansi pada perusahaan sektor perbankan di Indonesia. Adapun kasus terkait praktik perataan laba tersebut yaitu kasus PT Bank Bukopin Tbk pada tahun 2018. Dalam kasus ini PT Bank Bukopin ditemukan melakukan pencatatan tak wajar alias abnormal dari sisi pendapatan bisnis kartu kredit dan penambahan saldo cadangan kerugian penurunan nilai asset. Tim penyidik mendapatkan bahwa perusahaan memodifikasi data kartu kredit yang dilakukan dari 5 tahun yang lalu. Total kartu kredit yang dimodifikasi cukup banyak yaitu lebih dari 100.000 kartu. Modifikasi tersebut mengakibatkan posisi kredit dan penghasilan berbasis komisi Bukopin bertambah tidak semestinya. Akibat dari adanya kesalahan penyajian pada piutang kartu kredit tersebut, Bank Bukopin harus merevisi laba bersihnya pada tahun 2016 dari sebelumnya Rp 1,08 Triliun turun menjadi Rp 183,56 miliar. Penurunan terbesar adalah di bagian pendapatan provisi dan komisi yang merupakan pendapatan dari kartu kredit. Selain masalah kartu kredit, revisi juga terjadi pada pembiayaan anak usaha Bank Syariah Bukopin (BSB) terkait penambahan cadangan kerugian penurunan nilai asset. Akibatnya, beban penyisihan kerugian penurunan nilai atas asset keuangan direvisi meningkat dari Rp 649,05 miliar menjadi Rp 797,65 miliar. Hal ini menyebabkan beban perseroan meningkat $\mathrm{Rp} 148,6$ miliar (Rachman, 2018).

Jensen \& Meckling (1976) menjelaskan bahwa praktik perataan laba dipengaruhi oleh konflik kepentingan antara manajemen (agent) dan pemilik perusahaan (principal). Menurut teori keagenan (agency theory), perataan laba terjadi ketika semua pihak berusaha untuk mencapai atau mempertahankan tingkat kemakmuran yang dikehendakinya (Indrawan et al., 2018). Dalam praktiknya, distribusi informasi antara agent dengan principal itu tidak sama, karena manajer berada di dalam perusahaan sehingga memiliki informasi yang lebih banyak mengenai kondisi perusahaan dibandingan dengan pemilik perusahaan. Fenomena ini disebut dengan asimetri informasi. Asimetri informasi dapat terjadi ketika agen tidak mengungkapkan seluruh informasi mengenai kinerja perusahaan yang dimilikinya kepada principal (Liu, 2012). Alasan praktik perataan laba ini perlu diteliti karena mengakibatkan pengungkapan informasi mengenai laba menjadi keliru. Hal ini dapat mengakibatkan terjadinya kesalahan dalam pengambilan keputusan investasi oleh para investor.

Alasan penulis memilih perusahaan perbankan untuk diteliti karena fenomena kasus perataan laba yang belum lama terjadi di perusahaan perbankan yaitu Bank Bukopin Tbk pada tahun 2018 serta karena sektor perbankan adalah sektor sentral perekonomian bagi suatu negara, karena dari situlah asal jantung pendapatan suatu negara (Alexandri \& Anjani, 2014). Pengendalian yang dilakukan oleh pemerintah pun lebih kuat dari pada sektor industri yang lainnya. Hal ini membuat saham perbankan menjadi banyak diminati investor. Oleh sebab itu penulis ingin mengetahui apakah saat perusahaan yang banyak 
diminati para investor dan menjadi bahan ketertarikan pemerintah akan tetap menjalankan praktik perataan laba atau tidak, karena nantinya informasi laba yang akan diperoleh oleh pengguna laporan keuangan akan digunakan sebagai pengambilan keputusan investasi.

Hasil penelitian sebelumnya, mengenai pengaruh nilai perusahaan pada praktik perataan laba yang dilakukan oleh Auliyah et al. (2017) dan Pratiwi \& Damayanthi (2017) yang menunjukkan hasil bahwa nilai perusahaan berpengaruh positif pada praktik perataan laba, tetapi penelitian Adi (2015) dan Permanasari \& Suryanawa (2018) menunjukkan hasil bahwa nilai perusahaan tidak berpengaruh terhadap praktik perataan laba.

Hasil penelitian sebelumnya, mengenai ukuran perusahaan yang dilakukan Ayunika \& Yadnyana (2018), Sari \& Kristanti (2015) dan Pratiwi \& Damayanthi (2017) menunjukkan bahwa ukuran perusahaan berpengaruh positif pada praktik perataan laba. Disamping itu, penelitian Andiani \& Astika (2019) dan Anggi \& Suryanawa (2019) menemukan hasil yang berbeda yaitu ukuran perusahaan berpengaruh negatif pada praktik perataan laba.

Hasil penelitian sebelumnya mengenai proftabilitas yang dilakukan oleh Pratiwi \& Damayanthi (2017), Ayunika \& Yadnyana (2018) dan Sari \& Kristanti (2015) menunjukan hasil bahwa profitabilitas berpengaruh positif pada praktik perataan laba, sedangkan Suryani \& Damayanti (2015), Adi (2015) dan Trisnawati et al. (2017) menumkan bahwa profitabilitas berpengaruh negatif pada praktik perataan laba.

Menurut Sudana (2009:7) dalam Auliyah et al. (2017) tujuan suatu perusahaan adalah memaksimumkan nilai perusahaan atau kekayaan bagi pemilik perusahaan. Pernyataan tersebut dapat dikaitkan pada teori keagenan yang menyatakan bahwa adanya kontrak antara pemilik perusahaan (principal) dan manajemen (agent), dimana agent diharapkan dapat berperilaku sesuai dengan tujuan principal. Salah satu tujuan principal tersebut, yaitu untuk memperoleh laba yang stabil.

Nilai perusahaan yang tinggi berarti citra perusahaan dianggap baik bagi investor sehingga investor berkeinginan membeli saham tersebut. Ketika perusahaan sudah mendapatkan penilaian yang baik dari investor, maka perusahaan tersebut akan berusaha mempertahankannya atau bahkan meningkatkannya. Hal tersebut didorong oleh adanya peluang bagi perusahaan untuk mendapatkan tambahan modal dari investor baru maupun dari tambahan peningkatan volume dan harga saham yang sudah dilepas di pasar modal. Perusahaan yang posisi nilai perusahaannya tinggi, maka bisa melakukan berbagai keputusan strategis jangka panjang yang sebelumnya tidak bisa dilakukan. Keleluasaan itulah yang mendorong perusahaan yang memiliki nilai perusahaan yang tinggi akan melakukan praktik perataan laba (Auliyah et al., 2017). Hal tersebut sesuai dengan hasil penelitian Auliyah et al. (2017) dan Pratiwi \& Damayanthi (2017) menemukan hasil bahwa nilai perusahaan berpengaruh positif pada praktik perataan laba.

$\mathrm{H}_{1}$ : Nilai perusahaan berpengaruh positif pada praktik perataan laba.

Ukuran perusahaan merupakan skala untuk mengklasifikasikan besar atau kecilnya suatu perusahaan. Berdasarkan political cost hypothesis dalam teori akuntansi positif yang menjelaskan bahwa manajemen perusahaan besar 
cenderung memilih metode akuntansi yang dapat membuat laba yang dilaporkan menjadi lebih rendah apabila biaya politik yang ditanggung oleh perusahaan cukup tinggi. Perusahaan besar diduga akan menghindari fluktuasi laba yang terlalu drastis, sebab kenaikan laba yang terlalu tinggi akan membuat perusahaan mendapatkan pajak yang tinggi. Namun, penurunan laba yang terlalu drastis akan menyebabkan kesan negatif bagi perusahaan karena kinerja perusahaan akan dianggap kurang baik. Menurut Barton \& Simko (2002) yang menyatakan bahwa perusahaan berukuran sedang dan besar lebih memiliki tekanan yang kuat dari para pemegang sahamnya, agar kinerja perusahaan sesuai dengan harapan para investornya dibandingkan dengan perusahaan kecil. Maka dari itu, manajemen pada perusahaan besar diperkirakan memiliki kecenderungan yang lebih besar untuk melakukan praktik perataan laba. Hal tersebut didukung oleh penelitian yang dilakukan oleh, Sari \& Kristanti (2015), Masyithoh (2017) serta Ayunika \& Yadnyana (2018) yang menemukan hasil bahwa ukuran perusahaan berpengaruh positif pada praktik perataan laba.

$\mathrm{H}_{2}$ : Ukuran perusahaan berpengaruh positif pada praktik perataan laba.

Profitabilitas merupakan rasio yang digunakan untuk mengukur kemampuan perusahaan dalam menghasilkan laba bersih (Kasmir, 2014). Berdasarkan teori keagenan menjelaskan bahwa perbedaan kepentingan antara manajemen (agen) dan pemilik perusahaan (prinsipal), menyebabkan munculnya keinginan manajemen untuk melakukan disfunctional behavior, yaitu melakukan praktik perataan laba. Teori sinyal juga memiliki hubungan dengan profitabilitas yaitu informasi mengenai kinerja perusahaan dapat diartikan sebagai sinyal yang baik (good news) maupun sinyal yang buruk (bad news) (Bae et al., 2018)

Stabilitas tingkat laba dapat diperoleh dengan meminimalkan atau memaksimalkan laba pada periode tertentu dimana hal ini lebih mudah dilakukan oleh perusahaan dengan tingkat profitabilitas yang tinggi karena manajemen tahu akan kemampuan perusahaan untuk mendapatkan laba pada masa mendatang sehingga memudahkan dalam menunda atau mempercepat laba. Oleh karena itu, perusahaan dengan profitabilitas yang tinggi cenderung melakukan praktik perataan laba dibandingkan perusahaan dengan tingkat profitabilitas lebih rendah. Hal tersebut sesuai dengan hasil penelitian yang dilakukan Pratiwi \& Damayanthi (2017), Ayunika \& Yadnyana (2018) dan Masyithoh (2017) menemukan bahwa profitabilitas berpengaruh positif pada praktik perataan laba.

$\mathrm{H}_{3}$ : Profitabilitas berpengaruh positif pada praktik perataan laba.

\section{METODE PENELITIAN}

Penelitian ini dilakukan pada perusahaan Perbankan yang terdaftar di Bursa Efek Indonesia periode 2016-2018. Data diperoleh dengan mengakses dan mengunduh data laporan keuangan dari situs resmi Bursa Efek Indonesia, yaitu www.idx.co.id serta situs resmi perusahaan yang bersangkutan. Objek dalam penelitian ini adalah praktik perataan laba yang dipengaruhi oleh nilai perusahaan, ukuran perusahaan dan profitabilitas.

Perataan laba diukur menggunakan perhitungan Indeks Eckel. Menurut Nejad \& Alavi (2013) bahwa terdapat dua alasan yang mendasari digunakannya Indeks Eckel, yaitu indeks ini tidak menggunakan penilaian subjektif untuk 
memprediksi laba dan memperkirakan biaya, serta indeks ini tidak hanya menggunakan dari periode satu tahun saja Adapun untuk menghitung Indeks Eckel menggunakan rumus sebagai berikut (Eckel, 1981).

Indeks Eckel $=\frac{\mathrm{CV} \Delta \mathrm{I}}{\mathrm{CV} \Delta \mathrm{S}}$

Keterangan:

$\mathrm{CV}=$ Koefisien variasi dari variabel, yaitu standar deviasi dibagi dengan nilai yang diharapkan

$\Delta \mathrm{I}=$ Perubahan laba bersih setalah pajak dalam satu periode.

$\Delta S=$ Perubahan pendapatan dalam satu periode.

Untuk menghitung $\mathrm{CV} \Delta \mathrm{I}$ atau $\mathrm{CV} \Delta \mathrm{S}$ dapat digunakan rumus:

$\mathrm{CV} \Delta \mathrm{I}=\sqrt{\frac{\Sigma(\Delta \mathrm{I}-\overline{\Delta \mathrm{I}})^{2}}{\mathrm{n}-1}}: \overline{\Delta \mathrm{I}}$

$\mathrm{CV} \Delta \mathrm{I}=\sqrt{\frac{\sum(\Delta \mathrm{S}-\overline{\Delta S})^{2}}{\mathrm{n}-1}}: \overline{\Delta S}$

Keterangan:

$\Delta \mathrm{I}=$ Perubahan laba bersih setelah pajak antara tahun $\mathrm{n}$ ke tahun $\mathrm{n}-1$

$\Delta S=$ Perubahan pendapatan antara tahun $\mathrm{n}$ ke tahun $\mathrm{n}-1$

$\overline{\Delta I}=$ Perubahan rata-rata laba bersih setelah pajak tahun $n$ ke tahun $n-1$

$\overline{\Delta S}=$ Perubahan rata-rata pendapatan bersih antara tahun $n$ ke tahun $n-1$

$\mathrm{n}$ = Banyaknya tahun yang diamati.

Kriteria perusahaan yang melakukan praktik perataan laba, yaitu perusahaan dianggap melakukan praktik perataan laba apabila hasil perhitungan Indeks Eckel lebih kecil dari $1(\mathrm{CV} \Delta \mathrm{I}<\mathrm{CV} \Delta \mathrm{S})$, maka perusahaan yang melakukan perataan laba akan diberi nilai 1. Sedangkan perusahaan dianggap tidak melakukan praktik perataan laba apabila hasil perhitungan Indeks Eckel lebih besar atau sama dengan 1 (CV $\Delta \mathrm{I} \geq \mathrm{CV} \Delta \mathrm{S})$, maka perusahaan yang tidak melakukan perataan laba akan diberi nalai 0 .

Nilai perusahaan pada sektor perbankan yang terdaftar di Bursa Efek Indonesia (BEI) periode 2016-2018 dalam penelitian ini diukur dengan Price to Book Value (PBV) yang dihasilkan dari rasio antara nilai pasar ekuitas perusahaan terhadap nilai buku ekuitas perusahaan. Berikut rumus untuk menghitung Price to Book Value (PBV), yaitu sebagai berikut.

$\mathrm{PBV}=\frac{\text { harga pasar saham }}{\text { Nilai buku }}$

Ukuran perusahaan pada sektor perbankan yang terdaftar di Bursa Efek Indonesia (BEI) periode 2016-2018 dalam penelitian ini diukur menggunakan logaritma natural dari total asset. Adapun rumus dari ukuran perusahaan, sebagai berikut.

Ukuran Perusahaan $=$ Ln Total aset

Profitabilitas pada perusahaan sektor perbankan yang terdaftar di Bursa Efek Indonesia (BEI) periode 2016-2018 dalam penelitian ini diukur menggunakan Retur On Assets (ROA) yang menggunakan return atas modal sendiri. Adapun rumus untuk menghitung ROA sebagai berikut :

$\mathrm{ROA}=\frac{\text { Laba bersih setelah pajak }}{\text { Total Asset }} \times 100 \%$ 
Populasi dalam penelitian ini adalah seluruh perusahaan perbankan yang terdaftar di Bursa Efek Indonesia periode 2016 - 2018. Metode penentuan sampel yang digunakan dalam penelitian ini adalah dengan metode nonprobability sampling dengan teknik purposive sampling. Teknik purposive sampling merupakan teknik penentuan sampel dengan pertimbangan kriteria-kriteria tertentu (Sugiyono, 2017:144).

\section{Tabel 1. Hasil Seleksi Pemilihan Sampel}

\begin{tabular}{clc}
\hline No & \multicolumn{1}{c}{ Kriteria } & Jumlah \\
\hline 1 & Perusahaan perbankan yang terdaftar secara berturut-turut di & 43 \\
& Bursa Efek Indonesia pada periode 2016-2018 & \\
2 & $\begin{array}{l}\text { Perusahaan perbankan yang dalam laporan keuangan mengalami } \\
\text { kerugian selama tahun 2016-2018 }\end{array}$ & (12) \\
& Jumlah perusahaan yang memenuhi kriteria sampel & 31 \\
& Jumlah pengamatan selama tahun 2016-2018 & 93 \\
\hline
\end{tabular}

Sumber : Data Penelitian, 2019

Pengujian hipotesis dilakukan dengan menggunakan model regresi logistik. Pengujian menggunakan regresi logistik karena cocok digunakan untuk penelitian yang variabel terikatnya bersifat dikotomi (melakukan perataan laba dan tidak melakukan perataan laba) dan jika asumsi multivariate normal distribution tidak terpenuhi (Ghozali, 2016:325). Adapun model statistic untuk menguji hipotesis, sebagai berikut :

$\operatorname{Ln} \frac{P L}{1-P L}=\alpha+\beta_{1} X_{1}+\beta_{2} X_{2}+\beta_{3} X_{3}+\varepsilon$

Keterangan.

Ln $\frac{P L}{1-P L} \quad=$ Dummy variabel Praktik Perataan Laba ( 1 untuk perataan laba dan 0 tidak perataan laba

\begin{tabular}{|c|c|}
\hline a & $=$ Konstanta \\
\hline $\mathrm{X}_{1}$ & $=$ Nilai Perusahaan \\
\hline$X_{2}$ & $=$ Ukuran Perusahaa \\
\hline$X_{3}$ & $=$ Profitabilitas \\
\hline & $=$ error \\
\hline$\Omega \quad \Omega$ & $=$ Koefisien Regresi \\
\hline
\end{tabular}

\section{HASIL DAN PEMBAHASAN}

Statistik deskriptif dilakukan untuk memberikan informasi mengenai karakteristik variabel penelitian, yaitu jumlah sampel, nilai minimum, nilai maksimum, nilai rata-rata, dan standar deviasi. Hasil statistik deskriptif penelitian ini dapat dilihat pada Tabel 2, berikut.

\section{Tabel 2. Hasil Uji Statistik Deskriptif}

\begin{tabular}{llllll}
\hline & $\mathrm{N}$ & Minimum & Makimum & Mean & Std. Deviation \\
\hline Nilai Perusahaan & 93 & 0,04 & 4,72 & 1,5954 & 1,03860 \\
Ukuran Perusahaan & 93 & 14,62 & 20,98 & 17,6883 & 1,78913 \\
Profitabilitas & 93 & 0,12 & 3,13 & 1,2117 & 0,72800 \\
Perataan Laba & 93 & 0 & 1 &, 55 & 0,500 \\
Valid N (listwise) & 93 & & & & \\
\hline S
\end{tabular}

Sumber : Data Penelitian, 2019 
Nilai perusahaan (X1) yang diukur dengan Price to Book Value (PBV), memiliki nilai minimum sebesar 0,04 yang diperoleh oleh PT Bank Tabungan Negara Tbk pada tahun 2016 dan nilai maksimum sebesar 4,72 yang diperoleh oleh PT Bank Ina Perdana Tbk pada tahun 2017. Nilai rata-rata (mean) dari PBV perusahaan perbankan yang terdaftar di BEI pada tahun 2016-2018 adalah sebesar 1,5954 dengan standar deviasi 1,03860. Harus bisa jawab Hal ini menunjukkan penyebaran data dengan hasil yang normal dan tidak menyebabkan bias dengan standar deviasi lebih kecil dibandingkan nilai ratarata (mean).

Ukuran perusahaan (X2) yang diukur dengan Ln total asset, memiliki nilai minimum sebesar 14,62 yang diperoleh oleh PT Bank Mitraniaga Tbk pada tahun 2016 dan nilai maksimum sebesar 20,98 yang diperoleh oleh PT Bank Rakyat Indonesia Tbk pada tahun 2018. Nilai rata-rata (mean) dari Ln total aset perusahaan perbankan yang terdaftar di BEI pada tahun 2016-2018 adalah sebesar 17,6883 dengan standar deviasi 1,78913. Hal ini menunjukkan penyebaran data dengan hasil yang normal dan tidak menyebabkan bias dengan standar deviasi lebih kecil dibandingkan nilai rata-rata (mean).

Profitabilitas (X3) yang diukur dengan Return on Asset (ROA), memiliki nilai minimum sebesar 0,12 yang diperoleh oleh PT Bank Ganesha Tbk pada tahun 2018 dan nilai maksimum sebesar 3,13 yang diperoleh oleh PT Bank Central Asia Tbk pada tahun 2018. Nilai rata-rata (mean) dari ROA perusahaan perbankan yang terdaftar di BEI pada tahun 2016-2018 adalah sebesar 1,2117 dengan standar deviasi 0,72800. Hal ini menunjukkan penyebaran data dengan hasil yang normal dan tidak menyebabkan bias dengan standar deviasi lebih kecil dibandingkan nilai rata-rata (mean).

Perataan Laba (Y) yang diukur menggunakan Indeks Eckel merupakan variabel dummy. Nilai 1 diberikan untuk perusahaan perbankan yang terdaftar di BEI pada tahun 2016-2018 yang melakukan praktik perataan laba, sedangkan nilai 0 untuk perusahaan perbankan yang terdaftar di BEI pada tahun 2016-2018 yang tidak melakukan praktik perataan laba. Nilai rata-rata (mean) praktik perataan laba sebesar 0,55 yang berarti 55 persen dari 31 perusahaan perbankan selama tiga tahun pengamatan (2016-2018) terbukti melakukan praktik perataan laba, sedangkan sisanya sebesar $45 \%$ dari 31 perusahaan perbankan selama tiga tahun pengamatan (2016-2018) tidak melakukan praktik perataan laba. Nilai standar deviasi sebesar 0,500, ini menunjukkan penyebaran data dengan hasil yang normal dan tidak menyebabkan bias dengan standar deviasi lebih kecil dibandingkan nilai rata-rata (mean).

Kelayakan model regresi logistik dinilai dengan menggunakan Hosmer and Lemeshow's Goodness of Fit Test. Hasil pengujiannya disajikan pada Tabel 3, sebagai berikut.

Tabel 3. Hasil Uji Hosmer and Lemeshow Test

\begin{tabular}{llll}
\hline Step & Chi-square & df & Sig. \\
\hline 1 & 12,485 & 8 & 0,131
\end{tabular}

Sumber : Data Penelitian, 2019

Berdasarkan Tabel 3, menunjukkan hasil bahwa nilai chi-square sebesar 12,485 dengan nilai signifikansi sebesar 0,131 yang lebih besar dari 0,05 sehingga 
disimpulkan bahwa model mampu memprediksi nilai observasinya atau dengan kata lain dapat diterima karena cocok dengan data observasinya.

Menilai Keseluruhan model (Overall Model Fit). Pengujian dilakukan dengan membandingkan nilai antara -2 Log Likelihood (-2LL) pada awal (Block Number $=0$ ) dengan -2 Log Likelihood (-2LL) pada akhir (Block Number $=1)$. Hasil pengujian yang ditampilkan dalam Tabel 4, sebagai berikut.

Tabel 4. Perbandingan Nilai -2LL Awal dengan Nilai -2LL Akhir

$$
\begin{array}{ll}
\text {-2LL awal (Block Number }=0) & 128,053 \\
\text {-2LL akhir (Block Number }=1) & 116,897
\end{array}
$$

Sumber : Data Penelitian, 2019

Berdasarkan Tabel 4, menunjukkan hasil bahwa nilai -2LL awal sebesar 128,053 dan nilai -2LL akhir mengalami penurunan menjadi 116,897. Penurunan nilai -2LL tersebut menunjukkan bahwa model regresi yang lebih baik atau dengan kata lain model yang dihipotesiskan fit dengan data.

Nilai Nagelkerke $R$ Square menunjukkan nilai variabilitas variabel terikat yang dapat dijelaskan oleh variabel bebas, sedangkan sisanya dijelaskan oleh variabel-variabel lain diluar model penelitian ini. Hasil pengujian dapat ditampilkan dalam Tabel 5, sebagai berikut.

Tabel 5. Hasil Uji Koefisien Determinasi (Nagelkerke R Square)

\begin{tabular}{cccc}
\hline Step & -2 Log likelihood & Cox \& Snell R Square & Nagelkerke R Square \\
\hline 1 & $116,897^{a}$ & 0,113 & 0,151 \\
\hline
\end{tabular}

Sumber : Data diolah 2019

Berdasarkan Tabel 5, menunjukkan bahwa nilai Nagelkerke $R$ Square yaitu sebesar 0,151 atau sama dengan 15,1 persen. Nilai tersebut berarti variabilitas variabel terikat dapat dijelaskan oleh variabel bebas hanya sebesar 15,1 persen, sedangkan sisanya sebesar 84,9 persen dijelaskan oleh variabel-variabel lain di luar model penelitian atau yang tidak dimasukkan dalam penelitian ini.

Pengujian multikolinearitas dalam regresi logistik dapat dilihat dari matriks korelasi. Hasil pengujian dapat ditampilkan dalam Tabel 6, sebagai berikut.

\begin{tabular}{|c|c|c|c|c|c|}
\hline & & Constant & $\begin{array}{l}\text { Nilai } \\
\text { Perusahaan }\end{array}$ & $\begin{array}{l}\text { Ukuran } \\
\text { Perusahaan }\end{array}$ & Profitabilitas \\
\hline \multirow[t]{4}{*}{ Step 1} & Constant & 1,000 & $-0,272$ & $-0,982$ & 0,488 \\
\hline & Nilai Perusahaan & $-0,272$ & 1,000 & 0,176 & $-0,288$ \\
\hline & Ukuran Perusahaan & $-0,982$ & 0,176 & 1,000 & $-0,590$ \\
\hline & Profitabilitas & 0,488 & $-0,288$ & $-0,590$ & 1,000 \\
\hline
\end{tabular}

Tabel 6. Hasil Uji Matriks Korelasi

Sumber : Data Penelitian, 2019

Berdasarkan Tabel 6, menunjukkan nilai koefisien korelasi antar variabel yaitu lebih kecil dari 0,8 sehingga dapat disimpulkan bahwa tidak terdapat gejala multikolinearitas yang serius antar variabel bebas.

Berdasarkan hasil pengujian matriks klasifikasi pada Tabel 7, kekuatan model regresi untuk memprediksi kemungkinan perusahaan tidak melakukan praktik perataan laba yaitu sebesar 52,4 persen. Hal ini menunjukkan bahwa dari 42 total observasi yang tidak melakukan perataan laba terdapat 22 total observasi diprediksi tidak melakukan perataan laba, sedangkan 20 total observasi diprediksi melakukan perataan laba. Kekuatan prediksi dari kemungkinan 
perusahaan melakukan praktik perataan laba yaitu sebesar 72,5 persen. Hal ini menunjukkan bahwa dari 51 total observasi yang melakukan perataan laba terdapat 14 total observasi diprediksi tidak melakukan perataan laba, sedangkan 37 total observasi diprediksi melakukan perataan laba.

Matriks klasifikasi ini menunjukkan kekuatan prediksi dari model regresi untuk memprediksi kemungkinan terjadinya praktik perataan laba yang dilakukan oleh perusahaan perbankan yang terdaftar di BEI periode 2016-2018. Hasil pengujian ditampilkan dalam Tabel 7, sebagai berikut.

Tabel 7. Hasil Uji Matriks Klasifikasi

\begin{tabular}{|c|c|c|c|c|}
\hline & \multicolumn{2}{|c|}{ Predicted } & \multirow[b]{3}{*}{$\begin{array}{l}\text { Percentage } \\
\text { Correct }\end{array}$} \\
\hline & & \multicolumn{2}{|c|}{ Perataan Laba } & \\
\hline & & $\begin{array}{l}\text { Tidak } \\
\text { Perataan Laba }\end{array}$ & Perataan Laba & \\
\hline step 1 & Perataan Laba TidakPerataan Laba & 22 & 20 & 52,4 \\
\hline & $\begin{array}{l}\text { Perataan Laba } \\
\text { Overall Percentage }\end{array}$ & 14 & 37 & $\begin{array}{l}72,5 \\
63,4\end{array}$ \\
\hline
\end{tabular}

Sumber : Data Penelitian, 2019

Pengujian hipotesisi dilakukan dengan tingkat kesalahan (a). Apabila sig<a $(0,05)$ maka dapat dikatakan variabel bebas berpengaruh signifikan pada variabel terikat. Hasil pengujian regresi disajikan pada Tabel 8, sebagai berikut.

Tabel 8. Hasil Uji Regresi Logistik

\begin{tabular}{llllllll}
\hline & & B & S.E & Wald & df & Sig. & $\operatorname{Exp}(B)$ \\
\hline Step 1 $^{\text {a }}$ & Nilai Perusahaan & 0,501 & 0,242 & 0,285 & 1 & 0,038 & 1,650 \\
& Ukuran Perusahaan & 0,414 & 0,161 & 6,653 & 1 & 0,010 & 1,513 \\
& Profitabilitas & 0,600 & 0,399 & 2,259 & 1 & 0,133 & 0,549 \\
& Constant & 7,173 & 2,663 & 7,256 & 1 & 0,007 & 0,001 \\
\hline
\end{tabular}

Sumber : Data Penelitian, 2019

Berdasarkan Tabel 8, diperoleh bahwa pengujian model regresi yang terbentuk sebagai berikut.

$$
\operatorname{Ln} \frac{P L}{1-P L}=-7,173+0,501 X_{1}+0,414 X_{2}-0,600 X_{3}+\varepsilon
$$

Nilai konstanta (a) sebesar -7,173 (bernilai negatif) memiliki arti bahwa tanpa adanya pengaruh dari variabel bebas yaitu nilai perusahaan, ukuran perusahaan dan profitabilitas maka kecenderungan perusahaan melakukan praktik perataan laba akan menurun sebesar 7,173.

Variabel nilai perusahaan $\left(\mathrm{X}_{1}\right)$ menunjukkan koefisien regresi positif sebesar 0,501 memiliki arti bahwa jika nilai perusahaan meningkat sebesar satu satuan maka kemungkinan manajer melakukan praktik perataan laba juga meningkat sebesar 0,501 dengan asumsi variabel lainnya konstan. Berdasarkan hasil pengujian tersebut, diperoleh niai signifikansi dari nilai perusahaan yaitu 0,038 yang lebih kecil dari a $(0,05)$ sehingga $\mathrm{H}_{1}$ diterima. Maka dari itu, dapat disimpulkan bahwa nilai perusahaan berpengaruh positif pada praktik perataan laba.

Variabel ukuran perusahaan $\left(\mathrm{X}_{2}\right)$ menunjukkan koefisien regresi positif sebesar 0,414 memiliki arti bahwa jika ukuran perusahaan meningkat sebesar satu satuan, maka kemungkinan manajer melakukan praktik perataan laba juga akan meningkat sebesar 0,414 dengan asumsi variabel lainnya konstan. 
Berdasarkan hasil pengujian tersebut, diperoleh nilai signifikansi dari ukuran perusahaan yaitu 0,010 yang lebih kecil dari a $(0,05)$ sehingga $\mathrm{H}_{2}$ diterima. Maka dari itu, dapat disimpulkan bahwa ukuran perusahaan berpengaruh positif pada praktik perataan laba.

Variabel profitabilitas $\left(X_{3}\right)$ menunjukkan koefisien regresi negatif sebesar $-0,600$ memiliki arti bahwa jika profitabilitas meningkat sebesar satu satuan, maka kemungkinan manajer melakukan praktik perataan laba akan menurun sebesar 0,600 dengan asumsi variabel lainnya konstan. Berdasarkan hasil pengujian tersebut, diperoleh nilai signifikansi dari profitabilitas yaitu 0,133 yang lebih besar dari a $(0,05)$ sehingga $\mathrm{H}_{3}$ ditolak. Maka dari itu, dapat disimpulkan bahwa profitabilitas tidak berpengaruh pada praktik perataan laba.

Hipotesis pertama dengan menggunakan regresi logistik menghasilkan bahwa nilai perusahaan berpengaruh positif pada praktik perataan laba pada perusahaan perbankan di Bursa Efek Indonesia periode 2016-2018 sehingga $\mathrm{H}_{1}$ diterima. Hal ini mencerminkan nilai perusahaan yang diukur oleh Price Book Value (PBV) menunjukkan bahwa semakin tinggi nilai perusahaan, maka kecenderungan perusahaan melakukan praktik perataan laba semakin meningkat. Hal tersebut dikarenakan nilai perusahaan yang tinggi mengartikan bahwa citra perusahaan dianggap baik bagi investor sehingga investor berkeinginan membeli saham perusahaan tersebut (Aji \& Mita, 2010) dalam (Auliyah et al., 2017). Ketika perusahaan sudah mendapatkan penilaian yang baik dari investor, maka perusahaan tersebut akan berusaha mempertahankannya atau bahkan meningkatkannya. Salah satu usaha tersebut adalah melalui praktik perataan laba.

Hasil penelitian ini juga dapat mendukung teori keagenan yang menjelaskan manajemen (agent) memiliki mandat untuk mengelola perusahaan sesuai dengan tujuan pemilik perusahaan (principal). Salah satu tujuan principal tersebut, yaitu untuk memperoleh laba perusahaan yang stabil. Hal ini dapat mendorong manajemen untuk melakukan praktik perataan laba untuk menjaga laba yang dihasilkan stabil dan nilai perusahaan tetap tinggi, sehingga dapat menarik lebih banyak investor. Penelitian ini sejalan dengan penelitian Auliyah et al. (2017) dan Pratiwi \& Damayanthi (2017) yang menemukan hasil bahwa nilai perusahaan berpengaruh positif terhadap praktik perataan laba.

Hipotesis kedua dengan menggunakan regresi logistik menghasilkan bahwa ukuran perusahaan berpengaruh positif pada praktik perataan laba pada perusahaan perbankan di Bursa Efek Indonesia periode 2016-2018 sehingga $\mathrm{H}_{2}$ diterima. Hal ini mencerminkan ukuran perusahaan yang diukur oleh Log Natural total aset menunjukkan bahwa semakin besar ukuran perusahaan maka memiliki dorongan yang lebih besar untuk melakukan praktik perataan laba. Hal ini dikarenakan perusahaan besar akan mendapat lebih banyak perhatian dari berbagai pihak, seperti investor maupun pemerintah. Perusahaan besar akan menghindari fluktuasi laba yang terlalu drastis, sebab kenaikan laba yang drastis akan menyebabkan bertambahnya beban pajak. Sebaliknya penurunan laba yang drastis akan menunjukkan keadaan perusahaan yang kurang baik.

Hasil penelitian ini juga dapat mendukung political cost hypothesis pada teori akuntansi positif. Hipotesis tersebut menjelaskan bahwa perusahaan besar yang memiliki biaya politik tinggi, cenderung akan memilih metode akuntansi 
yang dapat membuat laba yang dilaporkan lebih rendah, karena didasari oleh motivasi untuk mengurangi beban pajak perusahaan. Penelitian ini sejalan dengan penelitian, Sari \& Kristanti (2015), Masyithoh (2017) serta Ayunika \& Yadnyana (2018) yang menemukan hasil bahwa ukuran perusahaan berpengaruh positif terhadap praktik perataan laba.

Hipotesis ketiga dengan menggunakan regresi logistik menghasilkan bahwa profitabilitas tidak berpengaruh pada praktik perataan laba pada perusahaan perbankan di Bursa Efek Indonesia periode 2016-2018 sehingga $\mathrm{H}_{2}$ ditolak. Hal ini mencerminkan profitabilitas yang diukur oleh Return on Asset (ROA) menunjukkan bahwa tinggi atau rendahnya tingkat profitabilitas tidak dapat mendorong manajer untuk melakukan praktik perataan laba. Hal ini dapat disebabkan oleh pertimbangan lain dari investor sebelum mengambil keputusan investasi. Investor tidak hanya mempertimbangkan rasio profitabilitas dalam mengambil keputusan investasi, tetapi juga mempertimbangkan rasio keuangan lainnya, seperti rasio aktivitas dan rasio investasi. Manajer perusahaan yang mengetahui hal tersebut, menyebabkan tinggi atau rendah tingkat profitabilitas tidak dapat menjadi dorongan untuk melakukan praktik perataan laba.

Hasil penelitian ini tidak dapat mendukung teori keagenan yang menjelaskan bahwa perbedaan kepentingan antara manajemen (agent) dan pemilik perusahaan (principal), menyebabkan munculnya keinginan manajemen untuk melakukan dysfunctional behavior, yaitu melakukan praktik perataan laba. Hasil penelitian ini juga tidak dapat mendukung teori sinyal yang menjelaskan bahwa tingkat profitabilitas yang tinggi dianggap sebagai sinyal yang baik (good news) sedangkan tingkat profitabilitas yang rendah dianggap sinyal yang buruk (bad news). Hal ini dikarenakan perusahaan dengan tingkat profitabilitas yang tinggi maupun rendah bisa saja melakukan praktik perataan laba, sehingga profitabilitas yang tinggi belum tentu merupakan sinyal yang baik digunakan investor dalam pengambilan keputusan berinvestasi, begitu pula sebaliknya. Penelitian ini sejalan dengan penelitian Yulfita (2014), Puspitasari \& Putra (2018) serta Anggi \& Suryanawa (2019) yang menemukan hasil bahwa profitabilitas tidak berpengaruh terhadap praktik perataan laba.

\section{SIMPULAN}

Nilai perusahaan berpengaruh positif pada praktik perataan laba pada perusahaan perbankan di Bursa Efek Indonesia periode 2016-2018. Hal ini menunjukkan bahwa semakin tinggi nilai perusahaan maka kecenderungan manajemen untuk melakukan praktik perataan laba semakin meningkat. Ukuran perusahaan berpengaruh positif pada praktik perataan laba pada perusahaan perbankan di Bursa Efek Indonesia periode 2016-2018. Hal ini menunjukkan bahwa semakin besar ukuran perusahaan maka manajemen memiliki dorongan yang lebih besar untuk melakukan praktik perataan laba. Profitabilitas tidak berpengaruh pada praktik perataan laba pada perusahaan perbankan di Bursa Efek Indonesia periode 2016-2018. Hal ini menunjukkan bahwa tinggi atau rendahnya tingkat profitabilitas tidak dapat mendorong manajemen untuk melakukan praktik perataan laba.

Berdasarkan hasil yang diperoleh, peneliti menyarankan bagi perusahaan diharapkan dapat meningkatkan pengawasan terhadap kinerja manajemen 
sehingga dapat meminimalisir praktik perataan laba yang tidak sesuai Standar Akuntansi Keuangan (SAK) yang berlaku. Bagi Investor sebaiknya memperhatikan proses bagaimana manajemen memperoleh dan memperlakukan laba tersebut misalnya dengan memperhatikan metode akuntansi yang digunakan. Bagi peneliti selanjutnya, diharapkan dapat memperluas sampel penelitian, menggunakan rentang waktu yang lebih panjang serta menambahkan beberapa variabel bebas yang diduga dapat mempengaruhi praktik perataan laba, seperti, bonus plan, leverage dan reputasi auditor.

\section{REFERENSI}

Adi, P. S. (2015). Pengaruh Profitabilitas, Risiko Keuangan, Nilai Perusahaan, Kepemilikan Manajerial, dan Dividend Payout Ratio Terhadap Praktik Perataan Laba. Jurnal Online Mahasiswa Fakultas Ekonomi, Vol. 2(1), 1-15.

Alexandri, M. B., \& Anjani, W. K. (2014). Income Smoothing: Impact Factors, Evidence in Indonesia. International Journal of Small Business and Entrepreneurship Research, 3(1), 21-27.

Anggi Adeliana Dewi, M., \& Suryanawa, I. K. (2019). Pengaruh Leverage, Bonus Plan, Ukuran Perusahaan, dan Profitabilitas pada Praktik Perataan Laba. EJurnal Akuntansi, 26, 58. https://doi.org/10.24843/eja.2019.v26.i01.p03

Auliyah, R., Saputri, Y. Z., \& Yuliana, R. (2017). Pengaruh Nilai Perusahaan, Pertumbuhan Perusahaan dan Reputasi Auditor terhadap Perataan Laba di Sektor Perbankan. Neo-Bis, 11(2), 122-140. https://doi.org/10.21107/nbs.v11i2.3361

Bae, S. M., Masud, M. A. K., \& Kim, J. D. (2018). A cross-country investigation of corporate governance and corporate sustainability disclosure: A signaling theory perspective. Sustainability (Switzerland), 10(8). https://doi.org/10.3390/su10082611

Barton, J. and P. J. S. (2002). The Balance Sheet as an Earnings Management Constraint. The Accounting Review, 77(1), 1-27.

Beattie, Vivien, Stephen, B. David, E. Brian, J. Stuart, M. Dylan, T. and Michael, T. (1994). Extraordinary Item and Income Smoothing: A Positive Accounting Approach. Journal of Business Finance and Accounting, 21(6).

Fischer, M., \& Rosenzweig, K. (1995). Attitudes of students and accounting practitioners concerning the ethical acceptability of earnings management. Journal of Business Ethics, 14(6), 433-444. https:/ / doi.org/10.1007/BF0072085

Gantino, R. (2015). Effect of Managerial Ownership Structure , Financial Risk and Its Value on Income Smoothing in the Automotive Industry and Food \& Beverage Industry Listed in Indonesia Stock Exchange. Research Journal of Finance and Accounting, 6(4), 48-56.

Ghozali, I. (2016). Aplikasi Ananlisis Multivariate dengan Program IBM SPSS 23. Semarang: BPFE Universitas Diponogoro.

Hejazi, R., Ansari, Z., Sarikhani, M., \& Ebrahimi, F. (2011). The Impact Of Earnings Quality And Income Smoothing On The Performance Of Companies Listed In Tehran Stock Exchange. International Journal of Business and Social Science, 2(17), 193-197.

Indrawan, Sukrisno Agoes, H. P. and O. M. J., \& Popoola. (2018). The Impact of Audit Committee, Firm Size, Profitability, and Leverage on Income 
Smoothing. Indian-Pacific Journal of Accounting and Finance (IPJAF), 2(1), 6174.

Jensen, M. and W, Meckling. (1976). Theory of the firm. Handbook on the History of Economic Analysis, 3, 553-562. https:/ / doi.org/10.4337/9781785365065.00043

Kasmir. (2014). Analisa Laporan Keuangan (satu). Jakarta: PT Raja Grafindo Persada.

Liu, J. (2012). Board Monitoring, Management Contracting and Earnings Management: An Evidence from ASX Listed Companies. International Journal of Economics and Finance, 4(12), 121-136. https://doi.org/10.5539/ijef.v4n12p121

Masyithoh, S. (2017). Tindakan Perataan Laba Pada Perusahaan Yang. Jurnal RAplikasi Manajemen Ekonomi Dan Bisnis, 1(2), 104-119.

Mushtaq, A., Sultan, H., \& Ijaz, F. (2016). Income Smoothing and Islam: Evidence from Pakistan Shariah Compliant Companies. Journal of Islamic Thought and Civilization, 06(02), 77-93. https://doi.org/10.32350/jitc.62.05

Nanda Ayunika, N. P., \& Yadnyana, I. K. (2018). Pengaruh Ukuran Perusahaan, Profitabilitasdan Financial Leverage Terhadap Praktik Perataan Laba Pada Perusahaan Manufaktur. E-Jurnal Akuntansi, 25, 2402. https://doi.org/10.24843/ eja.2018.v25.i03.p29

Nejad, H. S., Zeynali, S., \& Alavi, S. S. (2013). Investigation of Income Smoothing At the Companieslistedonthestock Exchange By the Using Index Eckel (Case Study: Tehran Stock Exchange). Asian Journal of Management Sciences and Educaition, 2(2), 49-62.

Nur Andiani, A. A. S., \& Astika, I. B. P. (2019). Pengaruh Struktur Kepemilikan dan Ukuran Perusahaan Pada Praktik Perataan Laba. E-Jurnal Akuntansi, 27, 984-1012. https:// doi.org/10.24843/ eja.2019.v27.i02.p06

Obaidat, A. N. (2017). Income Smoothing Behavior at the Times of Political Crises. International Journal of Academic Research in Accounting, Finance and Management Sciences, 7(2). https:// doi.org/10.6007/ijarafms/v7-i2/2752

Permanasari, N. M. D., \& Suryanawa, I. K. (2018). Kemampuan Good Corporate Governance Memoderasi Pengaruh Nilai Perusahaan pada Praktik Perataan. E-Jurnal Akuntansi, 22, 1004. https:// doi.org/10.24843/eja.2018.v22.i02.p07

Pratiwi, N. W. P. I., \& Damayanthi, I. G. A. E. (2017). Analisis Perataan Laba dan Faktor-faktor yang Mempengaruhinya. E-Jurnal Akuntansi Universitas Udayana, Vol. 20(1), 496-525.

Puspitasari, B., \& Putra. (2018). Pengaruh Profitabilitas Pada Praktik Perataan Laba dengan Struktur Kepemilikan Sebagai Variabel Pemoderasi. E-Jurnal Akuntansi, 23, 211-239. https://doi.org/10.24843/EJA.2018.v23.i01.p09

Rachman, F. F. (2018). Bank Bukopin Permak Laporan Keuangan, Ini Kata BI dan OJK. Diakses pada tanggal 30 November 2019, dari https:// finance.detik.com/moneter/d-3994551/bank-bukopin-permaklaporan-keuangan-ini-kata-bi-dan-ojk

Sari, R. P., \& Kristanti, P. (2015). Pengaruh umur, ukuran, dan profitabilitas perusahaan terhadap perataan laba. Jrak, 11(1), 77-88. https://doi.org/10.25134/jrka.v4i2.1693

Sugiyono. (2017). Metode Penelitian Bisnis Pendekatan Kuantitatif, Kualitatif, Kombinasi dan RED. Bandung: CV. Alfabeta. 
Suryani, A., \& Damayanti, E. (2015). Pengaruh Ukuran Perusahaan, Debt To Equity Ratio, Profitabilitas Dan Kepemilikan Saham Institusional Pada Perataan Laba. E-Jurnal Akuntansi, 13(1), 208-223.

Trisnawati, M., Nazar, R. M., \& Yudowati, P. S. (2017). Pengaruh Profitabilitas, Dividend Payout Ratio dan Financial Leverage Terhadap Praktik Perataan Laba (Studi Pada Perusahaan yang terdaftar pada Indeks LQ45 Tahun 20112016). E-Proceeding of Management, 4(3), 2654-2660.

Tudor, A. (2002). Income Smoothing and Earnings Informativeness A Matter of Institutional Characteristics or Accounting Standards. Assurance of PriceWaterhouse in Eindhoven, 1(1), 62-80.

Wang, Z., \& Williams, T. H. (2011). Accounting Income Smoothing And Stockholder Wealth. Journal of Applied Business Research (JABR), Vol. 10, p. 96. https:// doi.org/10.19030/jabr.v10i3.5929

Yulfita, D. (2014). Pengaruh Profitabilitas, Kebijakan Dividen, dan Pertumbuhan Perusahaan Terhadap Praktik Perataan Laba. Jurnal Ekonomi Universitas Negeri Padang. 